\title{
De arts Maatschappij \& Gezondheid verdient een rol in zowel de praktijk als de beleidsondersteuning
}

\author{
Jacqueline A. Deurloo,, ${ }^{1,2}$ Dylia T. Kuijvenhoven-Hagenaar ${ }^{1}$
}

\begin{abstract}
De GGD Hollands Noorden (GGD HN) heeft integraal management ingevoerd. De rayonmanager is verantwoordelijk voor eigen doelstellingen, medewerkers en middelen. De rayonmanager wordt inhoudelijk en beleidsmatig ondersteund door een algemeen beleidsmedewerker, stafverpleegkundige Jeugdgezondheidszorg (JGZ), epidemioloog en gezondheidsbevorderaar. ${ }^{1}$ De arts Maatschappij \& Gezondheid (M\&G) heeft hierin geen rol. Vrijwel alle artsen $M \& G$ binnen de GGD HN zijn werkzaam in de uitvoeringspraktijk: JGZ, Infectieziektenbestrijding (IZB) en Forensische Geneeskunde (FG). De overige artsen $M \& G$ zijn werkzaam in de staf en niet in de uitvoeringspraktijk. In deze situatie worden de competenties van de arts $M \& G$ op het niveau van beleid en management niet optimaal gebruikt.
\end{abstract}

\section{WAT IS HET PROBLEEM?}

'Beleid' kan worden omschreven als het formuleren van doelen en het aangeven van activiteiten en middelen waarmee men deze doelen wil behalen. Beleid is effectief als de beoogde doelen met de gehanteerde activiteiten en middelen worden bereikt en de effecten in voldoende mate aan het beleid kunnen worden toegeschreven. ${ }^{2}$ Het feit dat de arts $M \& G$ geen rol heeft in de beleidsondersteuning binnen de GGD HN kan leiden tot een aantal problemen.

Allereerst kan het gebrek aan invloed op het (intern) beleid bij de arts M\&G tot frustratie leiden. Dit kan vertragend werken bij implementatie van veranderingen. Vanuit de literatuur is bekend dat draagvlak bij professionals een belang-

1 GGD Hollands Noorden, Schagen

2 TNO Child Health, Leiden rijke voorwaarde is bij implementatie van veranderingen..$^{3-4} \mathrm{Het}$ betrekken van professionals (zoals de arts $M \& G$ ) bij de ontwikkeling van een verandering vergroot de kans op draagvlak en succesvolle implementatie. ${ }^{3-4}$

Ten tweede mist de GGD in de huidige situatie structurele feedback van de arts $M \& G$ vanuit de uitvoeringspraktijk op het beleid. In de uitvoeringspraktijk verzamelt de arts M\&G veel sociaal medische kennis en informatie die relevant kan zijn voor beleidsondersteuning. Deze kennis en informatie worden nu onvoldoende gebruikt.

Ten derde investeert de organisatie gedurende de opleiding van de arts M\&G veel in het opleiden van deze medisch specialist. Na de opleiding is de arts $M \& G$ in staat een sturende en vernieuwende rol te vervullen vanuit een heldere visie op het terrein van maatschappij en gezondheid en heeft hij de competenties verworven om een regierol binnen het werkveld te nemen. ${ }^{5}$ De organisatie zou meer profijt kunnen hebben van de resultaten van deze investering.

\section{EEN VERANDERENDE WERELD}

Wat verklaart de huidige situatie? Een mogelijke verklaring is de opleiding tot arts $M \& G$, deze is een aantal jaar geleden geheel vernieuwd. Voorheen werden artsen in vier jaar opgeleid tot sociaal geneeskundige met aandacht voor het eigen vakgebied, zoals JGZ/IZB/FG. Zij volgden daarnaast verbredende scholingen. Uit onderzoek in 2010 bleek dat artsen $M \& G$ beperkingen ervaarden om taken op het gebied van beleidsadvisering, management en onderzoek uit te voeren. ${ }^{6}$ Zij voelden zich onvoldoende toegerust en ervaarden onvoldoende ge- legenheid binnen de organisaties om deze taken te ontwikkelen en uit te voeren.

Tegenwoordig bestaat de opleiding uit twee fasen van twee jaar: de eerste fase is een beroepsgerichte profielopleiding en de tweede fase is gericht op beleid, management en wetenschappelijk onderzoek. Tijdens deze opleiding worden nu andere competenties ontwikkeld.

Naast de veranderingen in de opleiding, is ook de wereld binnen en buiten de organisatie veranderd. Gemeenten krijgen steeds meer taken op het gebied van publieke gezondheid en moeten met de huidige transities in het sociaal domein met minder middelen de taken anders gaan vormgeven. Ook binnen de GGD zijn veel organisatorische veranderingen gaande. Dit vraagt andere competenties van de GGD professionals.

Binnen de GGD HN volgen nu twee artsen de nieuwe opleiding tot arts M\&G. Dit is een relatief nieuwe ontwikkeling die zich ook bij andere GGD-en zal voordoen. De GGD moet nog ‘leren’ en ervaren wat de competenties zijn van deze nieuwe artsen $M \& G$ en hoe zij deze kan inzetten in een veranderende wereld.

\section{DE WINST VAN HET COMBINEREN VAN PRAKTIJKEN BELEID}

Er is winst te behalen als de arts M\&G naast de werkzaamheden in de uitvoeringspraktijk ook een rol speelt in beleidsondersteuning. De arts M\&G kent de gezondheid op populatieniveau en kan deze vertalen naar beleid op collectief niveau in het belang van de publieke gezondheid. ${ }^{7}$ De arts M\&G is hier voor opgeleid. Het competentieprofiel van de arts M\&G kent de volgende competenties die hiervoor van belang zijn: ${ }^{7}$ 
- Signaleren, analyseren en onderzoeken van gezondheidsrisico's: Door directe contacten met burgers, de leefomgeving, zorgprofessionals en andere ketenpartners, kunnen signalen worden opgepakt. De arts M\&G kan deze signalen sociaal medisch analyseren en interpreteren. Opvallende trends kunnen door de arts M\&G worden geanalyseerd en worden vertaald naar beleid en politiek.

- Verbindingen leggen binnen de gezondheidszorg: De arts M\&G kan bruggen slaan tussen preventie en curatie, en tussen eerste en tweede lijn. De arts M\&G spreekt dezelfde taal als collega-artsen en kan individueel en collectief/maatschappelijk belang onderscheiden en aan elkaar koppelen.

- Verbindingen leggen met andere sectoren: Gezondheid en ziekte worden beïnvloed door veel aspecten van de samenleving. Om deze reden is een hechte verbinding tussen volksgezondheid en de sociale sector, onderwijs, werk, landbouw, volkshuisvesting, ruimtelijke ordening en milieu van groot belang. De arts M\&G staat op de grens van gezondheid(szorg) en samenleving en heeft de positie en deskundigheid om te vertalen over de sectorgrenzen heen en mede daardoor verbindingen aan te brengen.

- Adviseren over passende zorg: Naast de individuele zorg kan de arts M\&G vanuit sociaal medische kennis op collectief niveau objectieve, goed onderbouwde en toepasbare adviezen geven over passende zorg, het inhoudelijk beleid van organisaties en de inrichting van het totale zorgsysteem.

- Medisch leiderschap: De arts M\&G heeft een brede medische en zorginhoudelijke expertise en heeft kennis van wetten, financiën en logistiek. De arts M\&G is in staat om opnieuw de verbinding te leggen tussen inhoud en vorm, of tussen zorginhoud en management.

De visie dat er in de publieke gezondheidszorg een sterkere relatie ontwikkeld moet worden tussen praktijk en beleid wordt ondersteund door recente rapporten. De commissie evaluatie basistakenpakket JGZ (beter bekend als de 'commissie de Winter') heeft in 2013 op ver- zoek van VWS een advies uitgebracht over een nieuw preventief basispakket JGZ. Deze commissie concludeert dat het onderdeel 'De JGZ levert beleidsinformatie en advies aan gemeenten en andere professionals' opgenomen moet worden in het basispakket van de JGZ. ${ }^{8}$

In een rapport over de toekomstige borging van de publieke gezondheid en de rol van de GGD wordt geconcludeerd dat de GGD, om te kunnen functioneren in een sterk veranderende wereld, onder andere sterker zal moeten worden in het benutten van kennis en informatie..$^{9-10}$ Hierin kan de arts M\&G een belangrijke rol spelen.

De visie van GGD HN op de rol van de arts $M \& G$ is aan het veranderen. Er komt meer aandacht voor de competenties van de arts M\&G op het gebied van beleid. Recent is nieuw opleidingsbeleid geformuleerd, waarin de taakomschrijving van de arts $M \& G$ is aangepast. De uitvoering van beleidstaken en het leveren van een bijdrage aan strategische advisering zijn nieuw opgenomen taken. ${ }^{11-12}$ In een recente vacature voor stafartsen JGZ is specifiek genoemd dat de beoogde stafarts opgeleid moet zijn als arts M\&G. De nieuwe stafarts zal deels werkzaam zijn in de uitvoering JGZ en deels als stafarts. ${ }^{13}$ De stafarts krijgt vanuit deze combinatie een rol in beleidsondersteuning.

\section{CONCLUSIE}

De arts M\&G is een hoog opgeleide professional die kennis heeft van de individuele en collectieve gezondheid, van beleid en management en van het leggen van verbindingen tussen professionals en ketenpartners. De arts M\&G spreekt de taal van zowel managers als beleidsmakers en kan waardevolle bruggen slaan. Deze specialist heeft te veel competenties om alleen maar werkzaam te zijn in de praktijk: zet deze specialist in waar deze voor is opgeleid!

\section{LITERATUUR}

1. GGD Hollands Noorden. Inhoudelijke ondersteuningsstructuur regio/rayon/ gemeente gericht. Schagen: GGD Hollands Noorden, 2013.

2. Aalst $M$ van der, Dijken JA van. Evaluatie van doeltreffendheid en doelmatigheid. Basis 2005 - 1. Leiden: Research voor Beleid, 2005.

3. Fleuren MAH, Jong ORW de. Basisvoorwaarden voor implementatie en borging van de standaarden Jeugdgezondheidszorg. Leiden: TNO, 2006.

4. Fleuren MAH, Paulussen TGWM, Dommelen $P$ van, Buuren $S$ van. Meetinstrument voor Determinanten van Innovaties (MIDI). Leiden: TNO, 2012.

5. http://www.nspoh.nl/opleidingen.php?action=view\&Opleiding_ld $=24 \& \mathrm{t}=$ medische-vervolgopleiding-maatschappij-gezondheid-mg-2e-fase. Geraadpleegd op 15-9-2014.

6. Meer $G$ de, Stiphout WA van, Groot B, Nellissen J. De positionering van de arts Maatschappij \& Gezondheid. Tijdschr Gezondheidswet 2010;88:425-6.

7. KAMG. De bevolking gezond houden. Position paper artsen Maatschappij \& Gezondheid. Utrecht: KAMG: 2012.

8. Commissie evaluatie basistakenpakket JGZ. Een stevig fundament. Evaluatie van het basistakenpakket jeugdgezondheidszorg. Utrecht: Commissie evaluatie basistakenpakket JGZ, 2013.

9. Andersson Elffers Felix. Borging van de publieke gezondheid en de positie van de GGD. Utrecht: Andersson Elffers Felix, 2013. Zie: http://www.vng.nl/files/vng/ 20140911-rapport-publieke-gezondheid.pdf

10. Veldhuisen A van. Publieke gezondheid en de toekomst van de GGD. Presentatie NCVGZ, deelsessie 10, 2104.

11. GGD Hollands Noorden. Functieomschrijving arts. Schagen: GGD Hollands Noorden, 2005.

12. GGD Hollands Noorden. Opleidingsbeleid, onderdeel Personeelsbeleid. Schagen: GGD Hollands Noorden, 2014.

13. GGD Hollands Noorden. Vacature 2 stafartsen Jeugdgezondheidszorg. Schagen: GGD Hollands Noorden, 2014.

Correspondentieadres Dr. Jacqueline Deurloo, GGD Hollands Noorden, Postbus 324, 1740AH Schagen, tel. 088-0100500, e-mail: jdeurloo@ggdhn.nl 